\title{
Effect of a Long-Term Acarbose Therapy on the Metabolic Control of Sulphonylurea-Treated Diabetic Patients
}

Dear Sir,

The blood glucose lowering effect of acarbose, an alpha-glucosidase inhibitor, has been adequately documented by short term studies [1-4]. However, a lack of effectiveness with longer term administration of acarbose in patients with Type 2 (non-insulin-dependent) diabetes has been reported [5].

In contrast to these findings, we would like to report our own results. After a 3-month prior period on sulphonylureas alone, 24 sulphonylurea-treated Type 2 diabetics (aged 53-79 years, Broca-index $>1,1$, mean post-prandial blood glucose $>11 \mathrm{mmol} / 1$, urinary glucose $>5 \mathrm{~g} / 24 \mathrm{~h}$ ) received in addition acarbose $300 \mathrm{mg} /$ day or placebo for 6 months. Afterwards, all patients continued with sulphonylureas alone for a further 3 months.

During administration of acarbose, we saw a significant lowering of the post-prandial blood glucose values ( $10.9 \pm 2.4$ compared with $16.0 \pm 3.6 \mathrm{mmol} / 1$, mean $\pm \mathrm{SD}, p<0.001)$, of mean daily blood glucose levels ( $8.6 \pm 1.7$ compared with $12.3 \pm 2.8 \mathrm{mmol} / \mathrm{l}$; $p<0.001)$, of 24 h urinary glucose excretion $(2 \pm 0.4$ compared with $13 \pm 6 \mathrm{~g} / 24 \mathrm{~h} ; p<0.005)$ and $\mathrm{HbA}_{\mathrm{la}-\mathrm{c}}$ values $(9.1 \pm 0.4$ compared with $12.4 \pm 0.6 \% ; p<0.005$ ).

Other laboratory determinations (fasting blood glucose, serum insulin, blood lipids, electrolytes, liver and kidney function) did not show any significant alterations during the entire study period. There was no change in body weight.

When acarbose was discontinued, the parameters specified above rose significantly again within 4 weeks (post-prandial blood glucose values: $14.9 \pm 3.2 \mathrm{mmol} / 1$; mean daily blood glucose levels: $12.7 \pm 2.3 \mathrm{mmol} / 1 ; 24 \mathrm{~h}$ urinary glucose excretion: $12 \pm 5 \mathrm{~g} / 24 \mathrm{~h}$ and $\mathrm{HbA}_{\mathrm{la}-\mathrm{c}}$ values: $\left.13.1 \pm 0.4 \%\right)$.

In the placebo group, there was no significant alteration of the metabolic state during the entire 12 months. Side effects (flatulence and meteorism) subsided after about 4 weeks and did not recur again during the rest of the experimental period.
Our results show that additional administration of acarbose to sulphonylurea-treated diabetics leads to a persistent improvement of metabolic control over a long period.

Yours sincerely

G. Sachse, H. Laube, E. Mäser and K. Federlin

\section{References}

1. Walton RJ, Sherif JT, Noy GA, Alberti KGMM (1979) Improved metabolic profiles in insulin-treated diabetic patients given an alpha-glucoside hydrolase inhibitor. Br Med J 1:220-221

2. Laube H, Fouladfar M, Aubell R, Schmitz H (1980) Zur Wirkung des Glukosidasehemmers Bay g 5421 (Acarbose) auf das Blutzuckerverhalten bei adipösen Erwachsenendiabetikern. Arzneim Forsch 30: 1154-1157

3. Sachse G, Willms B (1979) Effect of the alpha-glucosidase inhibitor Bay g 5421 on blood glucose control of sulphonylureatreated diabetics and insulin-treated diabetics. Diabetologia 17: $287-290$

4. Vierhapper H, Bratusch-Marrain P, Waldhäusl W (1978) Alphaglucoside hydrolase inhibition in diabetes. Lancet 2: 1386

5. Vierhapper H, Bratusch-Marrain P, Waldhäusl W (1981) Long term treatment of sulphonylurea-treated diabetics with the alpha-glucosidase inhibitor Bay g 5421 (Acarbose) Diabetologia 20:586 (Letter)

G. Sachse

III. Medizinische Universitätsklinik und Poliklinik

Rodthohl 6

D-6300 Giessen, FRG

\section{Subcutaneous Degradation of Insulin}

Dear Sir,

I would like to add some cautionary comments regarding the confusion over the extent of insulin degradation at the subcutaneous injection site in experimental animals and man reported in this journal [1] and elsewhere.

Evidence for considerable subcutaneous insulin degradation has been provided in rat [2,3] and pigs [4] and might partly explain the higher dose requirements when insulin is administered subcutaneously rather than intravenously or intramuscularly during at tempts to maintain normoglycaemia in diabetic man [5-9]. Indeed, adipose tissue of rats contains proteases which degrade insulin, and Paulsen et al. [7] showed a high level of insulin degrading activity in a homogenate of the adipose tissue of a patient with severe resistance to subcutaneously administered insulin.

However, confusion has arisen over whether the protease inhibitor aprotinin (Trasylol) can protect against insulin degradation at the subcutaneous site. It has been reported that aprotinin increases the rate and absolute amount of insulin absorption from the subcutaneous tissue of non-diabetics [10] and reduces the subcutaneous insulin requirements in some insulin-resistant diabetics $[9,11,12]$, while others have been unable to confirm these findings in a Type 1 (insulin-dependent) diabetic patient [8] or in Type 2 (non-insulin dependent) diabetic subjects [1]. However, the latter group did not report glycaemic changes and concluded that aprotinin had no ef- 